SECTION 32. Jurisprudence.

\author{
Nicholas Alexandrovich Mishchik \\ Associate Professor, Candidate of Technical Science, \\ Assistant professor Department of Navigation, \\ State Maritime University Admiral Ushakov, Russia, \\ minial@mail.ru
}

\title{
THE PRACTICE OF FRENCH JUSTICE ARTICLE 228 OF THE UN CONVENTION ON THE LAW OF THE SEA
}

Abstract: Examples of the application of Article 228 of the UN Convention on the Law of the Sea. This article allows the State to punish their flag vessels for pollution of the sea. In this case, the prosecution of the coastal State was terminated.

Keywords: pollution of the sea, the detention of the vessel, the pledge, the right of the flag State for investigation.

УДК 347.79

\section{ПРАКТИКА ПРИМЕНЕНИЯ ФРАНЦУЗСКИМ ПРАВОСУДИЕМ 228 СТАТЬИ КОНВЕНЦИИ ООН ПО МОРСКОМУ ПРАВУ}

Аннотация: Приведены примеры применения статьи 228 Конвенции ООН по морскому праву. Эта статья позволяет Государству флага наказывать свои суда за загрязнение моря. В этом случае судебное преследование прибрежным Государством прекрашцается.

Ключевые слова: загрязнение моря, задержание судна, залог, право Государства флага на проведение расследования.

Французская система борьбы с загрязнением моря является одной из репрессивной. Этой теме посвящены статьи [ ]. Но один пример стоит особо - это случай загрязнения с судна Vytautas. (IMO: 9133721, с 22.08.2008 Klaipeda Spirit).

5 июня 2007 г пилот самолета ВМС Франции, который патрулировал Бискайский залив, в 270 км юго-западнее городка Penmarch (недалеко от Бреста) обнаружил нефтяной шлейф длиной 37 км и шириной 50 м. Виновник загрязнения - грузовое судно Vytautas под литовским флагом, направляющееся в порт Elfa (Греция). Судно властями было направлено в Брест. После осмотра и уплаты судовладельцем компанией DFDS LISCO залога в 400000 евро, судно продолжило свой путь [1].

5 ноября 2008 года суд города Бреста начал судебное разбирательство, а свое решение он вынес 7 января 2009 года. Суд приговорил капитана к штрафу в размере 700 $000 €, 95 \%$ которого должен оплатить судовладелец. Это решение капитан и судовладелец обжаловали.

18 марта 2008 года суд литовского города Клайпеда за это же преступление загрязнение по неосторожности, осудил судовладельца DFDS LISCO и капитана Брониславаса Ругиниса к штрафу в размере 77750 литов (22 634 евро). Сумма штрафа с точки зрения французского правосудия смехотворная, равная стоимости сдачи льяльных вод в портах Европы.

20 января 2011 года Апелляционный суд города Ренн отказался от судебного преследования и отменил обвинительный приговор. Это первый случай, когда такое решение принято во Франции, и первый серьезный удар по действиям уголовного суда Бреста, известного своими жесткими приговорами [2]. 
Решение Апелляционного суда было основано на статье 228 Конвен-ции ООН по морскому праву. Статья называется «Приостановление и ограничение возбуждения разбирательства». Она гласит, что «разбирательство с целью наложения наказания за любое нарушение ... совершенное каким-либо иностранным судном за пределами территориального моря государства, возбуждающего разбирательство, приостанавливается, если государство флага возбуждает разбирательство с целью наказания по соответствующему обвинению...». Данное разбирательство приостанавливается на 6 месяцев. Эта же статья говорит, что «когда разбирательство, возбужденное государством флага, завершено, приостановленное разбирательство прекращается». Т.е. в данной статье заложена формула римского права ne bis in idem - никто не должен дважды нести наказание за одно преступление [3].

Апелляционный суд города Ренн призвал французские власти вернуть судовладельцу залог в размере 400000 евро. Это решение также основывается на этой же 228 статье. «После уплаты расходов, связанных с таким разбирательством, любой залог или другое финансовое обеспечение, внесенное в связи с приостановленным разбирательством, возвращается прибрежным государством».

Этот пример как бы говорит морякам, что 228 статья для них является спасательным кругом, чтобы избежать сурового приговора во французских судах. Но, однако, не всё так просто [4].

Рассмотрим еще два случая загрязнения, произошедшие почти одно-временно, но с различными судебными решениями.

Случай с химовозом Trans Arctic:

17 марта 2005, к югу от мыса Chassiron (остров Oleron, департамент Шаранта Приморская), в 37 милях от берега за кормой норвежского химовоза Trans Arctic самолет французской таможни зафиксировал загрязнение длиной 38 км. Судно следовало из порта Бордо.

Прокурор города Брест отдал распоряжение химовозу изменить маршрут и следовать в Брест. Через четыре дня Trans Arctic покинул порт после уплаты залога в 400 000 евро [5].

30 марта, посольство Франции в Норвегии была проинформировано о том, что Норвегия, как Государство флага, начала расследование предполагаемого загрязнения. Юрисдикция Норвегии утверждало о своей компетенции проводить это расследование, опираясь на статью 228 Конвенции ООН по морскому праву 1982 года. (Отметим, что данная конвенция в западной литературе чаще всего упоминается как конвенция Монтего Бей. Это город, в котором она была подписана). Данная конвенция предусматривает возможность Государству флага расследовать преступления, совершенные в исключительной экономической зоне Прибрежного Государства [6].

18 октября адвокат Trans Arctic подал прошение в суд Бреста на изменение места слушания, основываясь за заявление Норвегией, сделанной по дипломатическим каналам. Столкнувшись с этой новой ситуацией, суд Бреста приостановил процедуру разбирательства и отложил рассмотрение дела до 5 апреля 2006 года.

В те же дни, отвечая на вопрос о готовности Норвегии судить самого капитана, посол Норвегии в Париже Stale Slettebacken заявил, что “это важно для норвежских властей, что государства выполняют свои обязательства по защите и сохранению морской среды”. Выступая от имени министерства иностранных дел Норвегии, он сказал, что “как Государство флага, Норвегия обеспечивает соблюдение соответствующих норм и международных стандартов в отношении судов, плавающих под флагом Норвегии, независимо от места, где произошло предполагаемое преступление”.

29 декабря суд Бергена (Норвегия), приговорила компанию Euro Trans, судовладельца Trans Arctic к штрафу в размере 2800000 нор-вежских крон (350 $000 €)$. У 
судовладельца было несколько дней на апелляцию, но 5 января 2006 года судоходная компания сообщила, что она не будет обжаловать данный достаточно большой штраф.

Однако приостановленное во Франции разбирательство возобновилось в суде Бреста 5 апреля 2006 года. Адвокаты истцов в присутствии прокурора Республики настойчиво утверждали, что наказание в Норвегии представляет собой административный штраф, а не уголовное наказание.

Решение Франции было вынесено 7 июня в уголовном суде Бресте. Knut Havn, норвежский капитан химовоза Trans Arctic за умышленное за-грязнение 18 марта 2005 г. у побережья острова Oleron был приговорен к штрафу в размере 400000 евро.

Компания Euro Trans подала апелляцию во французский суд боле высокой инстанции. Решение суда Бреста впоследствии было отменено Апелляционным судом города Ренн (административный центр региона Бретань) постановлением от 27 сентября 2007 года.

Кассационный суд своим решением от 5 мая 2009 года заявил, что в процессуальных действиях, предпринятых судом высшей инстанции Бре-ста против капитана "Trans Arctic", плавающего под норвежским флагом, в отношении загрязнения судна во французской ИЭЗ суд Бреста отказал прямого применения статьи 228 Конвенции ООН по морскому праву [7].

Суд заявил, что судебный процесс во Франции против капитана нор-вежского судна прекращен после вступления в Норвегии в законную силу решения, и что суд Норвегии сделал правильное применение статьи 228 Конвенции Монтего Бей и статьи 4 (2) Конвенции МАРПОЛ.

Случай с судном Fast Independence:

22 мая 2005 года патрульный самолет французского ВМФ в 200 километрах от мыса Penmarc'h, регион Бретань, обнаружил нефтяное загрязнение 18,5 км в длину и 50 м в ширину. Виновник загрязнение ро-ро судно Fast Independence (бывшее Tango) под мальтийским флагом, 1984 года постройки, следовало из Роттердама в Бейрут с грузом строительной техники. Во время радиосвязи с бортом воздушного судна загрязнение было немедленно остановлено. Судно было направлено в порт Брест, где прокурор обязал судовладельца выплатить 400000 евро залога в качестве условия его освобождения.

Залог был оплачен достаточно быстро, 25 мая, но инспекторы Центра безопасности Северный Финистер (centre de sécurité du Nord-Finistère), которые выполняют функции офицеров Государственного портового контроля, при инспекции определили серьезные повреждения, требующие срочного ремонта. Носовое подруливающее устройство вышло из строя, электрические генераторы не работали должным образом, в машинном отделении скопилось большое количество воды. Механики на борту начали делать ремонт.

4 октября 2006 года суд Бреста приговорил к штрафу в 500000 евро египетского капитана судна Fast Independence. 90\% этого штрафа должен был оплатить египетский судовладелец Demline Egypt.

На суде также выступили французские инспекторы, который осмотрели судно в порту Бреста. Они дали показания, что в льялах машинного отделения судна было наводнение нефтесодержащих вод и что танки сбора отходов были переполнены сточными водами из-за различных утечек. Один из инспекторов сказал, что он никогда не видел такого количества нефтесодержащих вод на судне и добавил, что “это очень опасно, существовал риск возникновения пожара".

Капитан судна, Hussein Khalil, заявил суду на слушаниях, что причина загрязнения “ошибка экипажа” во время технического обслуживания балластного насоса.

Это решение суда было обжаловано судовладельцем, который утвер-ждал, что они уже оштрафованы властями Мальты, Государством флага. Дело в том, что морские Власти Мальты провели свое расследование, и 20 июня 2006 года осудили капитана к штрафу в размере 9500 мальтийских фунтов, что соответствует примерно 24000 евро. 
Апелляционный суд Ренна при рассмотрении дела Fast Independance напомнил, что статья 217 конвенции ООН по морскому праву в пункте 8 предусматривает, что «наказания, предусмотренные законами и правилами государств в отношении судов, плавающих под их флагом, должны быть достаточно суровыми для предупреждения нарушений, независимо от того, где они совершены». Аналогичная формулировка содержится и в конвенции МАРПОЛ в статье 4 пункт 4. Отсюда следует, что в случаях, когда разбирательство было начато прибрежным Государством, положения статьи 228 конвенции могут быть реализованы при условии, когда факты нарушения конвенции МАРПОЛ в Государстве флага заслужили значительных санкций, эквивалентных уровню, вынесенных юрисдикцией прибрежного Государства.

В этом случае суд посчитал, что Мальта как Государство флага установила смехотворный штраф в отношении судна-загрязнителя, что тождественно отсутствию уголовной ответственности в этом Государстве, что позволило Прибрежному государству вмешаться.

В своем решении Апелляционный суд Ренна отметил, что пять судов под мальтийским флагом были привлечены к ответственности за загрязне-ние побережья Франции с 2000 года и ни одно из них не был предметом судебного разбирательства на Мальте. А 228-ая статья имеет две «охранных оговорки», при которых Государство флага не может воспользоваться своим правом проведения судебного преследования. Это «когда разбирательство связано с тяжелым ущербом прибрежному государству или когда данное государство флага неоднократно не выполняло свое обязательство по эффективному обеспечению выполнения применимых международных норм и стандартов в отношении нарушений, совершенных его судами».

\section{Выводы}

Случай с грузовым судном «Fast Independence» показывает, что 228-ую статью нельзя рассматривать изолированно от других статей. Если быстрое прочтение 228-ой статьи дает надежду избежать строго наказания, то её две охранные оговорки и статья 237 пункт 8 окончательно эту надежду убивают.

Случай с химовозом «Trans Arctic» учит, что полезнее заплатить большой штраф родному Государства флага, чем эти же большие деньги отдать прибрежному Государству.

Случай с судном «Vytautas», скорее всего, какой-то сбой французской системы. Его невозможно объяснить никакими политическими мотивами.

\section{References:}

1. Мищик Н.А. Французская система борьбы с загрязнением моря. Вместо предисловия// Materialy X mezinarodni vedecko - prakticka konference «Efektivni nastroje modernich ved 2014». - Praha, 2014: Publishing House «Education and Science» s.r.o - 104 stran

2. Мищик Н.А. Французская система борьбы с загрязнением моря. Часть первая. Правовые основы. Конвенционные требования// Materia у X Miedzynarodowej naukowi-praktycznej konferencji «Europejska nauka XXI powieka - 2014» - Przemys1, 2014: Nauka i studia - 88 str.

3. Мищик Н.А. Французская система борьбы с загрязнением моря. Часть вторая. Правовые основы. Региональное сотрудничество// Материали за 10-а международна научна практична конференция, «Новината за напреднали наука», - 2014. - София, 2014: «Бял ГРАД-БГ» ООД - 96 стр.

4. Мищик Н.А. Французская система борьбы с загрязнением моря. Часть 2. Технические и правовые инструменты// Materialy X mezinarodni vedecko - prakticka konference «Vedecky pokrok na prelomu tysyachalety - 2014». - Praha, 2014: Publishing House «Education and Science» s.r.o - 98 stran. 
5. Мищик Н.А. Ответственность французской таможни с морскими загрязнениями// Materials of the $\mathrm{X}$ International scientific and practical conference, "Trends of modern science», - 2014 - Sheffield, 2014: Science and education - 92 p.

6. Мищик Н.А. Французская система борьбы с загрязнением моря. Часть 3. Судебная практика доказательства вины судна. Сбор доказательств вины судна// Materia у X Miedzynarodowej naukowi-praktycznej konferencji «Aktualne problem nowoczesnych nauk 2014» - Przemysl, 2014: Nauka i studia - 88 str.

7. Мищик Н.А. Ответственность капитана судна за загрязнение// Материали за 10-а международна научна практична конференция, «Злободневен извършване европейской наука - 2014», София, 2014: «Бял ГРАД-БГ» ООД - 86 стр. 